Available online at: $\mathrm{http}: / /$ proceeding.rsfpress.com/index.php/pss/index

LPPM UPN “Veteran" Yogyakarta Conference Series

Proceeding on Political and Social Science (PSS)

Volume 1 Number 1 (2020): 148-160

\title{
Village-Level Knowledge, Attitude, and Practice (KAP) on Solid Waste Management in Penampang, Sabah
}

\author{
Siti Yasmin Badrum, Mohammad Tahir bin Mapa \\ Universitas Pembangunan Nasional Veteran Yogyakarta \\ E-mail address: da1911001t@student.ums.edu.my; E-mail address: herma@ums.edu.my
}

\begin{abstract}
There Exploring the levels of knowledge, attitude, and practice (KAP) of the citizen is an initial step towards designing comprehensive and participative solid waste management strategies, programs, and policies. A cross-sectional survey was conducted to capture the knowledge, attitude, and practices (KAP) on solid waste management from a total of 107 respondents in Penampang Proper Village, Penampang, Sabah, Malaysia. The study determined the relationship of the independent variables (year of birth, gender, education, and employment) with the dependent variables (KAP) using the Kruskal Wallis correlation test. Relationships were tested at 0.05 levels of significance and Spearman Rho correlation was used to test the relationship between the KAP variables at 0.01 levels of significance. It was found out that most respondents have excellent levels of KAP but none of the independent variables has a significant relationship to the KAP levels. However, the respondents' year of birth and educational level has a significant relationship to their practice level. Spearman Rho test also reveals that knowledge and attitude have a positive correlation with each other. The findings, therefore, may be useful to assist local campaigners in planning message materials, platforms and input to further increase citizen participation
\end{abstract}

Keywords: KAP, knowledge, attitude and practice, solid waste management, solid waste management campaign, citizen participation

\section{INTRODUCTION}

This is an open access article under the CC-BY-NC license.

Globally, solid waste management is an unresolved problem. The annual waste generation is projected to increase by $70 \%$ from 2.01 billion tonnes in 2016 to 3.40 billion tonnes in 2050 due to rapid urbanization and population growth (World Bank, 2019). Managing waste proves to be more challenging for residents in developing countries as the impacts of unsustainably managed waste are ruthless, particularly to the urban poor as they are more prone to be the victim of diseases, accidents, and pollution (World Bank, 2019). This specific problem is the result of collective failure from the public, mismanagement of public funding, and ineffective policies, among others. Poor public knowledge and awareness will lead to a 
lack of participation and useless policies. To ensure the success of solid waste management programs, providing infrastructure is not sufficient, and more efforts should be put to understand public concerns, knowledge, and behavior (Babaei et al., 2015).

This study examined citizen's knowledge, attitude, and practice on waste management in Penampang Proper village, located in the district of Penampang in Sabah state, Malaysia. This small and densely populated settlement located at the Moyog river riverbank is often challenged with flash floods caused by accumulated waste, amongst others, as a result of the public's lack of knowledge and awareness of proper waste disposal (Abdullah, 2018). Additionally, the Moyog river was once dubbed as one of the dirtiest rivers in Sabah (Mat Hayin, 2017) and on-going efforts to preserve the cleanliness of the Moyog river has been actively conducted by several non-governmental organizations (NGOs) from the year 2012 until today (Sario, 2012). Therefore, this research was done to explore how citizens relate to the idea of proper and sustainable waste management practices across different sociodemographic factors and status and acknowledging their current practices. To begin, the paper situates this project within the wider field of solid waste management research and justify the focus on citizens' knowledge, attitude, and practices on waste management. Next, we observed how previous studies on sociodemographic differences and status in perceiving and practicing waste management were articulated that associated behavioral theories with knowledge and attitude. Using the selected methodology and sample, we explore various ways that people in Penampang Proper relate to the idea of waste management and reflect on sociodemographic differences and similarities. To conclude, we pinpoint the values that are expedient to policymakers towards building a mutual foundation across different layers of society in order to serve the public interest and reinforce societal transformation in waste management and sustainability.

\section{LITERATURE REVIEW}

According to Valente et. al. (1998), the unclear relationship between knowledge and behavior contributed, in some way, to the development of the KAP approach. Other behavioral theorists such as Ajzen, et. al. (1982) and Fishbein (1967) also argued that there is no clear and actual presence of a direct relationship between knowledge and behavior. It is then concluded that what an individual knows may influence his or her attitude of that particular subject and how they feel about it could influence their behavior (Schrader and Lawless, 2004). Alternatively, attitudes can also be supported by behavior, signifying that behavior may also affect attitudes (Fishbein, 1967). Attitudes can have an effect on what an individual perceives and will have an influence on his or her knowledge gains. However, knowledge or attitude is not necessarily a reliable indicator of behavior change (Ajzen and Fishbein, 1977). Thus, it may be concluded that these three dimensions are dynamic and reciprocal at times, and research conducted from the perspective and interaction of Knowledge-Attitude and Practice of Behaviour may yield beneficial information, particularly to policymakers.

The KAP survey was first used in studying the field of family planning and population in the 1950s. The surveys were devised to provide information on the knowledge, attitudes, and practices in the family planning that are appropriate for the creation of universal programs 
(Cleland, 1973). In the 1960s and 1970s, the KAP surveys were used widely to understand and investigate health behavior, as well as to gain more information on health-seeking practices (Hausmann-Muela et al. 2003). Presently, a similar convention was also proposed by Hiew et. al. (2015) in their research that stated accumulated knowledge could initiate modifications in attitudes that can result in gradual behavior change. People may be more willing to change their attitude and practicing behavioral change when they are confident with the specific knowledge that they obtained from diverse sources.

For decades, the Malaysian government has taken several actions to improve waste management conditions both in urban and rural areas. Starting in 1988, the Action Plan for a Beautiful and Clean (ABC) Malaysia was introduced, followed by the Reduce, Reuse, Recycle (3R) from 2001 to 2005. In 2006-2010, the Master Plan on National Waste Minimization was also introduced. Almost all of these programs were unsuccessful due to ineffective implementation and lack of public participation (Bashir, et al., 2019). The rise in waste generation further exacerbates the situation, as it was projected to reach 36,138 tons per day by $2020 ; 41,035$ tons per day by 2026 , and 49,670 tons per day by 2030 (Chua et al., 2019).

Different factors led to low participation from the community in solid waste management initiatives. Moh and Latifah (2016) observed that low participation is influenced by local authorities' incompetence, futile awareness campaigns, and insufficient policies on solid waste management, among others. In Putrajaya, Malaysia, low community engagement is largely due to the shortage of nearby facilities for waste segregation and recycling, as well as the lack of awareness campaigns. (Abdul Malik, Abdullah, and Abd Manaf, 2015). In Sakawi, Ayup, and Sukimi (2017), they reported that most respondents are highly aware of solid waste management, but they are unable to engage because of the lack of facilities for waste segregation in Negeri Sembilan, Malaysia, which also led to low practice. Due to the variations in causes and explanations for low participation, the rigorous study is important to identify and understand the participants in solid waste management systems in order to increase awareness, acceptance, and success rate (Tatlonghari and Jamias, 2010).

Numerous models have been developed to examine pro-environmental behavior with various theoretical structures, including the Theory of Planned Behavior, Responsible Environmental Behavior Models, Altruism Model, Empathy, and Value-Belief-Norm (VBN) and others. In addition to these models, there are other variables that can influence pro-environmental actions, such as demographic, institutional, economic, social, and cultural variables, motivation, awareness, attitudes, emotions, accountability, and so on. (Li, et. al., 2019). Since the early 2000s, there was an increase in studies that emphasized their focus on understanding public concerns, preferences, knowledge, and behavior to achieve the implementation of integrated solid waste management (Chung et. al., 2019). Therefore, it is critical to test and perform comprehensive theory-based surveys to clarify the factors responsible for citizen involvement in waste management programs. Evaluation of factors influencing these behaviors including knowledge, attitude, and practices (KAP) is integral towards the development of meaningful and adaptable solid waste management programs and policies for the public (Babaei et al. 2015). 


\section{RESEARCH METHODOLOGY}

The survey research design was used for this study, which was the most appropriate design to elicit the KAP variables (Tatlonghari and Jamias, 2010). The respondents were selected using snowball sampling, which is a nonprobability sampling. The sampling process and the questionnaire design were assured they did not in any way breach the privacy of the respondents. The questionnaire was divided into four sections:

Part A: Sociodemographic Information (7 questions)

Part B: Knowledge (10 questions)

Part C: Attitude (7 questions)

Part D: Practice (9 questions)

Responses for each question in the knowledge, attitude, and practice was given a score as in Table 1. The score for responses from all respondents was summed up to obtain the total score for the knowledge, attitude, and practice of solid waste management individually by the respondent. A scoring system adapted from Bloom's cut-off points was used to determine the respondents' level of KAP based on their total score obtained as shown in Table 2 (Nahida, 2007). Brief and casual interview on respondents' hands-on experiences with waste management were also conducted.

Table 1. Scoring System for Each Response of KAP

\begin{tabular}{|l|l|}
\hline Response & Score \\
\hline Knowledge & \\
\hline Yorrect Statement & 2 \\
Yes & 0 \\
No not know & 1 \\
False Statement & \\
\hline Yes & 0 \\
No & 2 \\
Do not know & 1 \\
\hline Attitude & \\
Agree & 2 \\
Not sure & 1 \\
Disagree & 0 \\
\hline Practice & \\
Positive practice & \\
\hline Daily & 4 \\
Weekly & 3 \\
Monthly & 3 \\
More than once in a month & 1 \\
Never & 0 \\
\hline
\end{tabular}


Negative practice

Daily

Weekly

Monthly

More than once in a month

Never

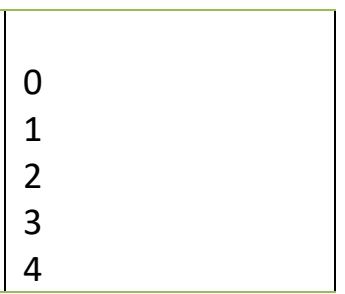

Table 2. Scoring System for Level of KAP

\begin{tabular}{|l|l|l|l|l|}
\hline Percentage & $\begin{array}{l}\text { The total score of } \\
\text { knowledge }\end{array}$ & $\begin{array}{l}\text { The total score of } \\
\text { attitude }\end{array}$ & $\begin{array}{l}\text { The total score of } \\
\text { practice }\end{array}$ & Level \\
\hline $80-100$ & $35-44$ & $13-16$ & $26-32$ & Excellent \\
\hline $60-79$ & $26-34$ & $10-12$ & $19-25$ & Good \\
\hline $40-59$ & $18-25$ & $8-9$ & $13-18$ & Adequate \\
\hline $0-39$ & $0-17$ & $0-5$ & $0-12$ & Poor \\
\hline
\end{tabular}

\section{FINDING AND DISCUSSION}

\section{IV.1.Sociodemographic Distribution}

A total of 107 individuals was obtained from a population of 319 individuals from Penampang Proper village in Penampang, Sabah. The sociodemographic distribution of the respondents is shown in Table 3.

Table 3. Sociodemographic Distribution of the Respondents $(\mathrm{N}=107)$

\begin{tabular}{|l|l|l|}
\hline Characteristics & N & Percentage \\
\hline Gender & & \\
Male & 54 & 50.5 \\
\hline Yemale & 53 & 49.5 \\
\hline 1965 to 1980 & & \\
1981 to 1996 & 40 & 37.4 \\
1997 to 2012 & 59 & 55.1 \\
\hline Education Level & 8 & 7.5 \\
\hline High School & & \\
Certificate & 30 & 28.0 \\
Diploma & 10 & 9.3 \\
Degree & 25 & 23.4 \\
Masters & 32 & 29.9 \\
PhD & 9 & 8.4 \\
\hline Employment & 1 & .9 \\
\hline Public & & \\
Private & 69 & 64.5 \\
\hline
\end{tabular}




\begin{tabular}{|l|l|l|}
\hline Business Owner & 4 & 3.7 \\
Self Employed & 7 & 6.5 \\
Homemaker & 3 & 2.8 \\
Student & 4 & 3.7 \\
Unemployed & 2 & 1.9 \\
Retiree & 1 & .9 \\
\hline
\end{tabular}

54 males and 53 females participated in this study. The majority of the respondents (59 individuals) were born between 1981 and 1996. The year of birth was organized according to the definition of the Pew Research Centre's generation categorization; from 1965 to 1980 (Gen-X), from 1981 to 1996 (Gen-Y), and from 1997 to 2012 (Gen-Z). The majority of the respondents $(65 \%)$ have an undergraduate education and is currently employed in the public sector $(64.5 \%)$.

\section{IV.2. Distribution of KAP Level of Solid Waste Management}

\section{IV.2.1. Knowledge of Solid Waste Management}

Most respondents understood essential concepts such as pollution and flooding as consequences of unsuitable waste management. The respondents were also familiar with terms such as recycling, landfills, open dumping, and composting. Table 4 shows the distribution of knowledge level (score) of solid waste management among the 107 respondents. The majority of respondents have an excellent level of knowledge $(\mathrm{N}=103)$ while the remaining 4 individuals have a good knowledge level.

Table 4Knowledge Level Among Respondents ( $\mathrm{N}=107)$

\begin{tabular}{|l|l|l|}
\hline Level (Score) & Total (N) & Percentage (\%) \\
\cline { 2 - 3 } Excellent (15-20) & 103 & 96.2 \\
\hline Good (10-14) & 4 & 3.7 \\
\hline Adequate (5-9) & 0 & 0 \\
\hline Poor (0-4) & 0 & 0 \\
\hline
\end{tabular}

Table 5. Comparison of Knowledge on Solid Waste Management with Respondents' Sociodemographic Variables Using Kruskal-Wallis Test

\begin{tabular}{|l|l|l|l|}
\hline Variables & N & Mean Rank & $p$-value \\
\cline { 2 - 4 } & & & .069 \\
\hline Male & 54 & 48.69 & \\
\hline Female & 53 & 59.42 & \\
\hline & & & \\
\hline Year of Birth & & & .174 \\
\hline
\end{tabular}




\begin{tabular}{|l|l|l|l|}
\hline 1965 to 1980 & 40 & 53.43 & \\
\hline 1981 to 1996 & 59 & 51.79 & \\
\hline 1997 to 2012 & 8 & 73.19 & \\
\hline & & & .367 \\
\hline Employment & & & \\
\hline Public & 69 & 50.73 & \\
\hline Private & 17 & 55.35 & \\
\hline Business Owner & 4 & 77.13 & \\
\hline Self Employed & 7 & 58.64 & \\
\hline Homemaker & 3 & 65.67 & \\
\hline Student & 4 & 65.5 & \\
\hline Unemployed & 2 & 75.5 & \\
\hline Retiree & 1 & 7.5 & .339 \\
\hline & & & \\
\hline Educational Level & & & \\
\hline High School & 30 & 48.78 & \\
\hline Certificate & 10 & 58.5 & \\
\hline Diploma & 25 & 60.60 & \\
\hline Degree & 32 & 56.45 & \\
\hline Masters & 9 & 44.5 & \\
\hline PhD & 1 & 7.5 & \\
\hline
\end{tabular}

Table 5 shows the comparison of knowledge amongst the sociodemographic variables using the Kruskal Wallis test. The analyses found out that gender, year of birth, employment and educational level did not have significant relationship with knowledge; gender $(p=.069,>$ $0.05)$, year of birth $(\mathrm{p}=.174,>0.05)$, employment $(\mathrm{p}=.367,>0.05)$ and educational level $(\mathrm{p}=.339,>0.05)$. The Kruskal Wallis test shows that there is no significant correlation between knowledge and gender, year of birth, employment, and educational level. The respondents mostly claim that they obtained their knowledge from the media but never participated in waste management events organized by the local authority. They also agreed that training should be conducted especially on recycling, composting, and waste segregation.

\section{IV.2.2.The attitude of Solid Waste Management}

Table 6 shows that the majority of the respondents possessed an excellent attitude towards solid waste management efforts in their own households and amongst the community $(\mathrm{N}=82$, 76.6\%). According to Tatlonghari and Jamias (2010), this indicates a positive factor in a solid waste management strategy that includes the creation or change of favorable attitudes. 
Table 6.Attitude Level Among Respondents (N=107)

\begin{tabular}{|l|l|l|}
\hline Level (Score) & Total (N) & Percentage (\%) \\
\hline Excellent (12-14) & 82 & 76.6 \\
\hline Good (8-11) & 25 & 23.4 \\
\hline Adequate (4-7) & 0 & 0 \\
\hline Poor (0-3) & 0 & 0 \\
\hline
\end{tabular}

Table 7. Comparison of Attitude of Solid Waste Management with Respondents' Sociodemographic Variables Using Kruskal-Wallis Test

\begin{tabular}{|l|l|l|l|}
\hline Variables & N & Mean Rank & p-value \\
\hline Gender & & & .429 \\
\hline Male & 54 & 51.74 & \\
\hline Female & 53 & 56.30 & \\
\hline Year of Birth & & & .067 \\
\hline 1965 to 1980 & & & \\
\hline 1981 to 1996 & 40 & 47.14 & \\
\hline 1997 to 2012 & 59 & 56.45 & \\
\hline & 8 & 70.25 & \\
\hline Employment & & & .508 \\
\hline Public & & & \\
\hline Private & 69 & 52.97 & \\
\hline Business Owner & 17 & 48.32 & \\
\hline Self Employed & 4 & 51.75 & \\
\hline Homemaker & 7 & 58.79 & \\
\hline Student & 3 & 80.83 & \\
\hline Unemployed & 4 & 50.25 & \\
\hline Retiree & 2 & 89.50 & \\
\hline & 1 & 60.50 & \\
\hline Educational Level & & & \\
\hline High School & & & \\
\hline Certificate & 30 & 48.28 & \\
\hline Diploma & 10 & 45.9 & \\
\hline Degree & 25 & 62.78 & \\
\hline Masters & 32 & 53.55 & \\
\hline PhD & 9 & 64.72 & \\
\hline
\end{tabular}

In Table 7, it is evident that there was no significant relationship between gender, year of birth, employment, and education with the attitude towards solid waste management. This 
suggests that most respondents that have an excellent and good level of attitude towards solid waste management are likely to be influenced by their personal observation and experiences to have more concern for the environment, rather than depending on sociodemographic standards (Welsch and Kuhling, 2010).

\section{IV.2.3.Practices of Solid Waste_Management}

The distribution of the practice level of solid waste management among the respondents is shown in Table 8 . The majority of the respondents $(n=46,43 \%)$ have a good practice level in solid waste management, while another 41 individuals have an excellent level of practice.

Table 8. Practice Level Among Respondents (N=107)

\begin{tabular}{|l|l|l|}
\hline Level (Score) & Number (n) & Percentage (\%) \\
\hline Excellent (28-36) & 41 & 38.3 \\
\hline Good (19-27) & 46 & 43.0 \\
\hline Adequate (9-18) & 19 & 17.8 \\
\hline Poor (0-8) & 1 & 0.9 \\
\hline
\end{tabular}

Table 9. Comparison of Practice of Solid Waste Management with Respondents' Sociodemographic Variables Using Kruskal-Wallis Test

\begin{tabular}{|l|l|l|l|}
\hline Variables & N & Mean Rank & p-value \\
\hline Gender & & & .114 \\
\hline Male & 54 & 58.69 & \\
\hline & 53 & 49.23 & \\
\hline Year of Birth & & & \\
\hline 1965 to 1980 & & & .035 \\
\hline 1981 to 1996 & 40 & 46.04 & \\
\hline 1997 to 2012 & 59 & 60.95 & \\
\hline & 8 & 42.56 & \\
\hline Employment & & & .058 \\
\hline Public & & & \\
\hline Private & 69 & 55.64 & \\
\hline Business Owner & 17 & 50.47 & \\
\hline Self Employed & 4 & 73.88 & \\
\hline Homemaker & 7 & 60.64 & \\
\hline Student & 3 & 29.33 & \\
\hline Unemployed & 4 & 23.5 & \\
\hline Retiree & 2 & 88.75 & \\
\hline & 1 & 1.00 & \\
\hline
\end{tabular}




\begin{tabular}{|l|l|l|l|}
\hline Educational Level & & & .020 \\
\hline High School & 30 & 65.05 & \\
\hline Certificate & 10 & 31.2 & \\
\hline Diploma & 25 & 47.58 & \\
\hline Degree & 32 & 53.08 & \\
\hline Masters & 9 & 67.5 & \\
\hline PhD & 1 & 19.00 & \\
\hline
\end{tabular}

In Table 9, the analyses found that practice was statistically significant $(p<0.05)$ with a year of birth, $\mathrm{X}^{2}\left(2{ }^{=} 6.717, p=.035\right)$, with a mean rank of the practice score of 46.04 for the year 1965 to $1980,60.95$ for the year 1981 to 1995 and 42.56 for the year 1997 to 2012. The posthoc analysis shows there are significant differences between the years 1965 to 1980 (Gen-X) and the year 1981 to $1996(\mathrm{Gen}-\mathrm{Y})(p=.056)$. These findings are consistent with Bieser (2015) that found that millennials (Gen-Y) have the tendency to describe sustainable consumption choices as a deliberate choice of consumption, whereas baby boomers (Gen$\mathrm{X})$ prefers to describe it more broadly in terms of environmental responsibility; implying that both groups are actually practicing pro-environmental behavior.

The educational level was also found significant with practice level $(p<0.05), \mathrm{X}^{2}(5)=$ $13.35, p=0.020$. The mean rank for high school is 65.05 , the certificate is 31.2 , a diploma is 47.58, Degree is 53.08, Master's Degree is 67.6 and Ph.D. is 19.00. Post-hoc analysis implied significant differences with those who have certificates and high school education. A study was done in Kampala, Uganda by Banga (2011) also found similar findings that indicated those in the lowest education category were more likely to engage in solid waste activities such as waste separation and recycling. She also concluded that those who have a higher level of education have low participation possibly because they are generally employed and earn stable income; and unlikely to depend on recyclables to supplement their income.

Table 10. Correlations between knowledge, attitudes, and practices in total respondents using Spearman Rho

\begin{tabular}{|l|l|l|l|}
\hline Variables & Knowledge & Attitude & Practice \\
\hline Knowledge & 1 & $.276^{\mathrm{a}}(p=.004)$ & .150 \\
\hline Attitude & $.276^{\mathrm{b}}(p=.004)$ & 1 & .113 \\
\hline Practice & .150 & .114 & 1 \\
\hline
\end{tabular}

${ }^{\mathrm{a}, \mathrm{b}}$ Correlation is significant at the $\mathrm{p}<0.01$ level (2-tailed)

In Table 10, a Spearman's rank-order correlation analyses display the relationship between knowledge and attitude (KA), knowledge and practice (KP), attitude and knowledge (AK), attitude and practice (AP), practice and knowledge (PK) as well as practice and attitude (PA). Only knowledge-attitude (KA) and attitude-knowledge (AK) have a positive correlation with each other which was statistically significant $\left(\mathrm{r}_{\mathrm{s}}=.276, p=.004\right)$. 
The association between knowledge and attitude suggests that most people value accurate information and use them to determine how they perceive about a particular issue. This result is significant as it would be helpful to recognize areas where information and education initiatives in future programs and policies can be improved. However, the knowledge and attitude level were not enough to persuade the desired change in the behavior of proper waste management practices among the respondents. In this study, we did not explore the reason why knowledge and attitudes do not translate into practices, but this needs further investigation for future research.

\section{CONCLUSION AND FURTHER RESEARCH}

Solid waste management in Malaysia is a never-ending problem. Programs and policies that were introduced by the government failed most of the time because of the lack of support and participation from the citizen. Policymakers have a vital role to play in socializing consumers in the skills of such participatory - the ability to challenge, analyze, debate, and reflect on their consumption behavior. This could be done by identifying and integrating adult-centric programs designed to increase awareness and education. In the long run, however, this should be the responsibility of the education system to further increase participation. It is also imperative that policymakers provided consumers-citizens with an additional mechanism to take actions and enabling them to be involved greatly in environmental policy formulation

A KAP survey uses a quantitative type method that has predefined questions and is constructed in standardized questionnaires. The result from a KAP survey typically will provide access to both quantitative and qualitative information as the KAP questions tend to uncover not only their knowledge, attitude, and behavior of an issue but also the idea of each person (in terms of culture, religion, social norms, and others) has of the issue discussed. This would help in understanding the obstacles and barriers to behavior change that may exist when implementing any particular program, policy, or campaign (Gumucio et. al., 2011).

This study is only limited to investigating the respondents' KAP level among a group of respondents that has similar sociodemographic elements. KAP studies should be supplemented with studies that would substantiate their findings and explore other behavioral aspects such as the dynamics affecting people's actions. While knowledge and attitude may have contributed to practice, it has been proven that assuming that knowledge alone leads to practice is incorrect. Variables in the Theory of Reasoned Action such as the behavioral norms that existed in the community should also be part of future KAP studies (Tatlonghari and Jamias, 2010). The KAP survey represents a significant first step in providing information for campaign planning and strategies as the KAP level of the respondents could be employed as a basis for considering the formula and direction of an extensive campaign strategy. The results of this study, therefore, may be considered to assist local campaign planners in designing message content, channels, and feedback for further improvement of the solid waste management system, programs, policies, and also better participation from the citizen. Ideally, converting intention into desirable behavior and 
establishing favorable socioeconomic and political environments should be the mutual focus of both the government and the citizen.

\section{REFERENCES}

Abdul Malik, N.K., Abdullah S. H., and Abd Manaf, L. (2015). Community participation in solid waste segregation through recycling programs in Putrajaya. Procedia Environmental Sciences.

Abdullah, M.I.U. (2018). Kempen Asing Sampah Organik di Penampang. Berita Harian. Retrieved from malaysia/20180519/282677572945247

Ahmad, J., Md. Noor, S., and Ismail, N. (2015). Investigating students' environmental knowledge, attitude, practice, and communication. Asian Social Science, 11(16), 284-293. https://doi.org/10.5539/ass.v11n16p284

Ajzen, I., \& Fishbein, M. (1977). Attitude-behavior relations: A theoretical analysis and review of empirical research. Psychological Bulletin, 84(5), 888-918.

Ajzen, I., Timko, C., \& White, J.B. (1982). Self-monitoring and the attitude-behavior relation. Journal of Personality and Social Psychology, 42(3), 426-435.

Babaei A.A., Alavi N., Goudarzi G., Teymouri P., Ahmadi K., and Rafiee M. (2015). Household recycling knowledge, attitudes, and practices of solid waste management. http://dx.doi.org/10.1016/j.resconrec.2015.06.014

Banga, M. (2011). Household Knowledge, Attitudes, and Practices in Solid Waste Segregation and Recycling: The Case of Urban Kampala. Zambia Social Science Journal: Vol. 2: No. 1, Article 4.

Barloa, E.P., Lapie, L.P., and Cruz, C.P.P. (2016). Knowledge, Attitudes, and Practices on Solid Waste Management among Undergraduate Students in a Philippine State University. Journal of Environment and Earth Science. Vol.6, No.6, 2016

Beall, J. (1997). Thoughts on Poverty from a South Asian Rubbish Dump: Gender, Inequality, and Household Waste. IDS Bulletin 28, no 3: 73-90

Bieser, S. (2015) Generational perceptions of pro-environmental packaging advantages. UmweltWirtschaftsForum 23(4): 315-322.

Chua H.S., Bashir M.J.K., Tan K.T., and Chua H.S. (2019). A sustainable pyrolysis technology for the treatment of municipal solid waste in Malaysia. AIP Conf Proc 2124:020016. https://doi. org/10.1063/1.5117076

Chung, C. Y., Yeong, W. M., Munusamy, K., Low, M. P., Nair, M., and Ung, L. Y. (2019). Government Initiatives and Public Awareness on Sustainable Environment. Journal of Tourism, Hospitality and Environment Management, 4(14), 40-50.

Du, P.T. (1995). The Determinants of Solid Waste Generation, Reuse, and Recycling by Households in Ho Chi Minh City, Vietnam. Master Thesis. Asian Institute of Technology, Bangkok, Thailand

Ekere, W., Mugisha J., and Drake, L. (2009). Factors Influencing Waste Separation and Utilization among Households in the Lake Victoria Crescent, Uganda. Waste Management 29: 3047-3051.

Fishbein, M. (1967). Attitude and the prediction of behavior. In M. Fishbein (Ed.), Readings in attitude theory and measurement (pp. 477-492). New York: John Wiley \& Sons

Gumucio, S., Merica, M., Luhmann, N., Fauvel, G., Zompi, S., Ronsse, A., Courcaud, A., Bouchon, M., Trehin, C., and Schapman, S. (2011). Data Collection Quantitative Methods, the KAP Survey Model (Knowledge, Attitude, and Practices); IGC communigraphie: Saint Etienne, France, 2011; p. 5.

Hausmann-Muela, S., Muela R. J., and Nyamongo, I. (2003). Health-seeking behavior and the health system's response. DCPP Working Paper no. 14. 
Hiew C.C., Chin Y.S., Chan Y.M., and Mohd Nasir M.T. (2015). Development and Validation of Knowledge, Attitude, and Practice on Healthy Lifestyle Questionnaire (KAP-HLQ) for Malaysian Adolescents. Journal of Nutrition and Health Sciences Volume 2, Issue 4

Li, D., Zhao, L., Ma, S., Shao, S., and Zhang, L. (2019). What influences an individual's proenvironmental behavior? A literature review. Resources, Conservation \& Recycling 146 (2019) $28-34$.

Mangiri, A., Iuliano, A.D., Wahyuningrum, Y., Praptiningsih, C.Y., Lafond, K.E., and Storms, A.D., (2017). Physician's knowledge, attitudes, and practices regarding seasonal influenza, pandemic influenza, and highly pathogenic avian influenza A (H5N1) virus infections of humans in Indonesia. Influenza Other Respir. Viruses 11 (1), 93-99.

Mat Hayin, N.A. (2017). Pulihkan Sungai Moyog. Harian Metro. Retrieved from https://www.hmetro.com.my/nuansa/2017/08/250473/pulihkan-sungai-moyog

Nahida, A. (2007). Knowledge, Attitude, and Practice of Dengue Fever Prevention among the people in Male', Maldives. Master Thesis. Chulalongkorn University.

Sakawi, Z., Ayup, S., and Sukimi, M.F. (2017). Pengetahuan komuniti dan amalan pengurusan sisa pepejal di Negeri Sembilan. GEOGRAFIA OnlineTM Malaysian Journal of Society and Space 13 issue $4(126-137)$

Sario, R. (2012). Campaign kicks off to clean Sungai Moyog. The Star. Retrieved from https://www.thestar.com.my/news/community/2012/03/22/campaign-kicks-off-to-clean-sungaimoyog

Shorofi, S.A., Arbon, P. (2017). Complementary and alternative medicine (CAM) among Australian hospital-based nurses: knowledge, attitude, personal and professional use, reasons for use, CAM referrals, and socio-demographic predictors of CAM users. Complement. Ther. Clin. Pract. 27, $37-45$.

Schrader, P.G., and Lawless, K. A. (2004). The Knowledge, Attitudes, and Behaviours Approach: How to Evaluate Performance and Learning in Complex Environments. Performance Improvement. Volume 43. Number 9. DOI: 10.1002/pfi.4140430905

Tatlonghari, R.V., and Jamias, S.B. (2010). Village-Level Knowledge, Attitudes, and Practices on Solid Waste Management in Sta. Rosa City, Laguna, Philippines. Journal of Environmental Science and Management 13(1):35-51(June 2010)

Valente, T. W., Paredes, P., and Poppe, P. R. (1998). Matching the message to the process: The relative ordering of knowledge, attitudes, and practices in behavior change research. Human Communication Research

Welsch, H., \& Kuhling, J. (2010). Pro-environmental behavior and rational consumer choice: Evidence from surveys of life satisfaction. Journal of Economic Psychology, 31(3), 405420. https://doi.org/10.1016/j.joep.2010.01.009

World Bank. Solid Waste Management (Online). https://www.worldbank.org/en/topic/urbandevelopment/brief/solid-waste-management.

Retrieved 23 August 2020 